\title{
Common ground and conviviality: Indonesians doing togetherness in Japan $^{1}$
}

\author{
Zane Goebel \\ La Trobe University/Tilburg University
}

\begin{abstract}
While Humanities and Social Science scholars have a long history of trying to understand how people from different backgrounds get along (i.e. to be convivial), typically this work misses much of the work carried out in sociolinguistics and related areas. In building upon work on common ground, small talk, and conviviality, this paper examines how a group of Indonesian students living in Japan go about practicing conviviality. I show how repetition and tiny response tokens are used to build common ground. I argue that this practice is key to building convivial relations amongst this group and that this type of interactional work helps open the possibility of future interactions, some of which are tied with the need to build and maintain support networks in Japan.
\end{abstract}

Keywords: conviviality; common ground; Indonesia; Japan; talk

\section{INTRODUCTION}

nthropologists, Sociologists, and
history of seeking to understand how
people from diverse backgrounds go
about getting along (e.g. Werbner 1997;
Ang 2003; Brettell 2003; Vertovec 2007;
Wise 2009). While recent work in this area
continues to highlight the importance of
everyday interaction in the building of
convivial relations (Thrift 2005; Landau
and Freemantle 2009; Wise 2009; Karner
and Parker 2010; Bunnell et al. 2012;
Amin 2013), bar Williams and Stroud's
(2013) work on public performances of
conviviality, the majority of these studies
do not focus on everyday talk and indeed
seem to have missed work on these issues in
the field of sociolinguistics (e.g. Gumperz
1982; Tannen 1984; Rampton 1995; Ryoo 2005).

Early anthropological work on reciprocity (e.g. Malinowski 1996 [1922]; Mauss 1966 [1925]) and later work by Goffman (1971) laid much of the groundwork for the study of conviviality. Goffman (1971), for example, showed how reciprocity related to all sorts of semiotic exchanges and social relations. Since this work, the interactional practices that build and maintain social relations have been investigated from the standpoint of 'common ground' (Enfield 2006) or 'small talk' (Coupland 2000, 2003). In the current paper I seek to synthesize these areas by examining how conviviality is built through talk among sojourning Indonesian students. I will argue that the 
use of small response tokens, repetition, and teasing all build and reproduce common ground and ultimately convivial social relations. Practicing conviviality is important for this group of sojourning Indonesians because it helps ensure access to important resources and information. In what follows I cover some of the earlier work on conviviality (Section 2), before then introducing the study and the participants (Section 3). I then analyze participants' talk in a television viewing session (Section 4) and an interview (Section 5).

\section{RECIPROCITY, CONVIVIALITY, AND COMMON GROUND}

Since Malinowski's (1996 [1922]) and Mauss' (1966 [1925]) classic works, reciprocity has become an important concept in anthropology, especially the idea that reciprocity is key to the building and maintenance of social relations. In one of his many opuses, Goffman (1971) argued that most human interaction involves reciprocity of one form or another.

[I]nterpersonal rituals have a dialogistic character, and this differently impinges on positive and negative rites. When a ritual offering occurs, when, that is, one individual provides a sign of involvement in and connectedness to another, it behooves the recipient to show that the message has been received, that its import has been appreciated, that the affirmed relationship actually exists as the performer implies, that the performer himself has worth as a person, and finally, that the recipient has an appreciative, grateful nature. Prestation (to use Mauss' favorite term) thus leads to counter-prestation, and when we focus on minor rituals performed between persons who are present to each other, the giving statement tends to be followed immediately by a show of gratitude. (Goffman 1971: 63-64)

The continued importance of reciprocity in anthropology can be seen in Wise's (2009) work, which focuses upon the giving and receiving of food, offers of assistance, recipes, lessons, and does so across lines of difference. In this work Wise (2009) suggests that through this type of reciprocal practice participants are building convivial relations by displaying mutual recognition of the other. If we look at some of the work on small talk, we also see that reciprocity seems to be an underlying feature of displays of recognition.

Studies of small talk show that recognition is done through the giving and receiving of compliments, the exchange of a joke for laughter (Ryoo 2005), repetition (Tannen 1989), the pursuit of sameness in states of being (Ryoo 2005), teasing (Strachle 1993), the use of response tokens (McCarthy 2003), and so on. McCarthy's (2003) work, for example, shows how a single response token (e.g. 'yes') indexes hearership, while the use of additional response tokens (e.g. 'yes, yes, heem') can index engaged listening, which is a type of conviviality. The use of additional response tokens is referred to as 'non-minimal response' (McCarthy 2003).

The use of non-minimal responses are part of a larger set of interactional practices referred to as repetition and the social pursuit of sameness (Bucholtz and Hall 2004; Lempert 2014), all of which help establish and maintain convivial relations. While there are many types of repetition, including memicity which involve replication of some elements and the addition of some new elements (discussed in the paper by Varis and Blommaert), this paper is more interested in replication-asprecise copy in conversation, and how this 
figures in the building and maintaining of social relations. As Tannen (1989), Berman (1998), Bjork-Willen (2007), and others have shown, repetition of others' words, utterances or embodied practices can index and produce positive interpersonal social relations. When interactants know little about each other, repetition can show that you have similar linguistic repertoires, dispositions, opinions, and so on. As a form of linguistic reciprocity, repetition may not only provide interactional recognition of the other, but also tacit approval of their ways of speaking, while also establishing common ground on which future interactions can be based (Enfield 2006). Enfield (2006: 422) defines common ground as 'knowledge openly shared by specific pairs, trios, and so forth'. Common ground is achieved through participants' ability to jointly agree on referents in interaction (Enfield 2006; Hanks 2006).

The interactional pursuit of common ground establishes convivial relations, while setting up a type of infrastructure for future social interaction (Goffman 1971). As Blommaert (2013) points out, these types of infrastructures are important to mobile persons who often do not have access to formal channels of help such as banking, schooling, and housing. In settings inhabited by mobile persons, the pursuit of conviviality is necessary for accessing information about housing options, employment options, the cheapest or best shops, and so on (Wise 2009; Bunnell et al. 2012; Blommaert 2013). In what follows, I look at the forms conviviality takes in talk amongst a group of sojourning Indonesian students. In doing so, these typically small and often minute orienting practices help conversationalists construct certain identities for themselves and others (Antaki and Widdicombe 1998), though as we learn more about identity in interaction it seems clear that identities are always emergent and produced over a series of speech events (Wortham 2006).

\section{METHODS AND PARTICIPANTS}

My data is drawn from recordings of talk that were made as part of a larger study conducted in Japan². This study examined how Indonesians interpreted and talked about televised soap operas. These Indonesians were all from a highly mobile middle-income population. They were primarily graduate students and/or the spouses of graduate students studying at a university in Nagoya. While this group of Indonesians clearly fit into what is essentially middle-class Indonesia, nevertheless like many post-graduate students across the world they were not wealthy and lived very frugal lives whilst in Nagoya. Typically their scholarships were small by Japanese standards, with most taking on part-time jobs to support themselves and their families.

As I became part of the Indonesian network in Nagoya, because of my long-term interest in Indonesia and also because of my Indonesian spouse, I learned that most of these Indonesian students lived in the old, yet-to-bemade earthquake proof, public housing located in the outer fringes of Nagoya. In many ways a comfortable life in Nagoya was made possible through the support networks that had emerged through their own efforts and through their predecessors' efforts. One such network was the Nagoya branch of the Indonesian Student Union of Japan (PPI Japan).

This network provided: lists of people who knew Japanese; lists of people who knew the cheapest places to buy furniture, clothes, appliances; information about where and when 
houses may become vacant and how to work with (or around) bureaucracy to ensure you had a place to live. The setting where this research was conducted-in a room located within a building that housed the Saturday school for the children of Indonesian sojourners-was one of the hubs of this network. While some participants either had children in this school or were involved in the running of the school, others were part of the Nagoya Indonesian community who would come together on Saturdays to exchange information (e.g. about accommodation, food, clothing, upcoming gatherings), to organize the settling in or return preparations for sojourners, the organization of national and religious celebrations, and to share food or to do the evening prayer together in the case of Muslim Indonesians.

Seventeen Indonesians voluntarily responded to an advertisement seeking participants for this study. Given what we know about the ubiquitousness of communal viewing practices in Indonesia (Hobart 2001; Nilan 2001; Rachmah 2006; Goebel 2010), and with the help of a couple of Indonesian research assistants, we divided respondents into viewing groups of four to five people and invited them to attend four viewing and interview sessions over four weeks. Each viewing session lasted between one to two hours. Typically, sessions started with some informal chatting with participants about the research project, about participants' backgrounds, and about local events. Following this, a comedic soap opera or a film was screened. These screenings were audio and video-taped. After the screening, I interviewed participants using a mixture of pre-devised questions and questions that had arisen as a result of participants' talk during the viewing session. What I will present in my analysis is the talk that occurred between participants during the first viewing session. A summary of participant backgrounds is presented in table 3.1 (all names are pseudonyms).

This group of participants consisted of five people, me, and an Indonesian research assistant. As can be seen in table 3.1 most participants were highly multilingual. With the exception of Desi and my research assistant, they were also rather mobile. Participants were of similar age (except Lina), and were highly educated. Diagram 3.1 shows where each participant was seated. All of these participants knew each other to varying degrees through their interaction within the Indonesian community in Nagoya. Slamet and Lina, a husband and wife couple, had only recently arrived in Japan and were not well acquainted with the other participants who had all lived in Nagoya for a number of years. While the methods used here differed from those used in much of the work on small talk and other studies of social relations, this context offers a number of opportunities to focus on how people do conviviality through talk. Despite the artificial context, this group still needed to build and/or reproduce interpersonal relations because of their need to continue to access the support networks described earlier. This helps explain why these participants continued to attend these viewing sessions over the six-week period that they ran, rather than not attending after the first session.

Before looking at this talk I want to provide some background information about the comedic soap which this group of Indonesians watched and talked about. The episode they watched was titled Cipoa ('Con artist'). It was part of the series Noné ('Young Miss') that was broadcast nationally in 1995 during the mid-afternoon time slot on the commercial, semi-educational 
Table 3.1 Participant backgrounds

\begin{tabular}{|c|c|c|c|c|c|}
\hline \multirow[t]{2}{*}{ Name } & \multirow[t]{2}{*}{ Age } & \multicolumn{2}{|c|}{ History of mobility } & \multirow[t]{2}{*}{ Education } & \multirow[t]{2}{*}{ Language ability } \\
\hline & & Years & Place & & \\
\hline Desi (S) & 35 & $\begin{array}{l}27 \\
3 \\
5\end{array}$ & $\begin{array}{l}\text { Bandung } \\
\text { Solo } \\
\text { Japan }\end{array}$ & MA & $\begin{array}{l}\text { Indonesian } \\
\text { Sundanese } \\
\text { Japanese } \\
\text { English }\end{array}$ \\
\hline Lina & 23 & $\begin{array}{l}8 \\
3 \\
9 \\
1 \\
1.5 \\
0.5\end{array}$ & $\begin{array}{l}\text { Pekan Baru } \\
\text { Jakarta } \\
\text { Padang } \\
\text { Japan } \\
\text { Padang } \\
\text { Japan }\end{array}$ & BA & $\begin{array}{l}\text { Indonesian } \\
\text { Japanese }\end{array}$ \\
\hline Slamet & 33 & $\begin{array}{l}21 \\
5 \\
0.5 \\
2 \\
4 \\
0.5\end{array}$ & $\begin{array}{l}\text { Irian } \\
\text { Bandung } \\
\text { Jakarta } \\
\text { Japan } \\
\text { Padang } \\
\text { Japan }\end{array}$ & MA & $\begin{array}{l}\text { Javanese } \\
\text { Indonesian } \\
\text { English }\end{array}$ \\
\hline Gun (S) & 37 & $\begin{array}{l}19 \\
6 \\
4 \\
8\end{array}$ & $\begin{array}{l}\text { Cirebon } \\
\text { Bandung } \\
\text { Jakarta } \\
\text { Japan }\end{array}$ & PHD & $\begin{array}{l}\text { Javanese } \\
\text { Sundanese } \\
\text { Indonesian } \\
\text { Japanese } \\
\text { English }\end{array}$ \\
\hline RA & 39 & $\begin{array}{l}27 \\
10 \\
2\end{array}$ & $\begin{array}{l}\text { Solo } \\
\text { Jakarta } \\
\text { Japan }\end{array}$ & BA & $\begin{array}{l}\text { Javanese } \\
\text { Indonesian } \\
\text { Japanese }\end{array}$ \\
\hline Me & 41 & $\begin{array}{l}35 \\
3.5 \\
0.5 \\
2\end{array}$ & $\begin{array}{l}\text { Australia } \\
\text { Semarang } \\
\text { Cirebon } \\
\text { Japan }\end{array}$ & PHD & $\begin{array}{l}\text { Indonesian } \\
\text { Javanese } \\
\text { Sundanese } \\
\text { English }\end{array}$ \\
\hline
\end{tabular}

television station TPI. This particular comedic soap is notable because of some characters' frequent alternation between Indonesian and linguistic fragments stereotypically associated with a regional language, Sundanese, and because of the representation of other signs that anchored the linguistic signs and the story geographically to West Java, an area associated with an imagined community of Sundanese speakers.

\section{SMALL RESPONSE TOKENS AND CONVIVIALITY}

Throughout the viewing of this soap opera the use of small response tokens and repetition figured in the building and reproduction of common ground and convivial relations. As we will see, participants' ponderings over the meaning of a particular word, cipoa, 


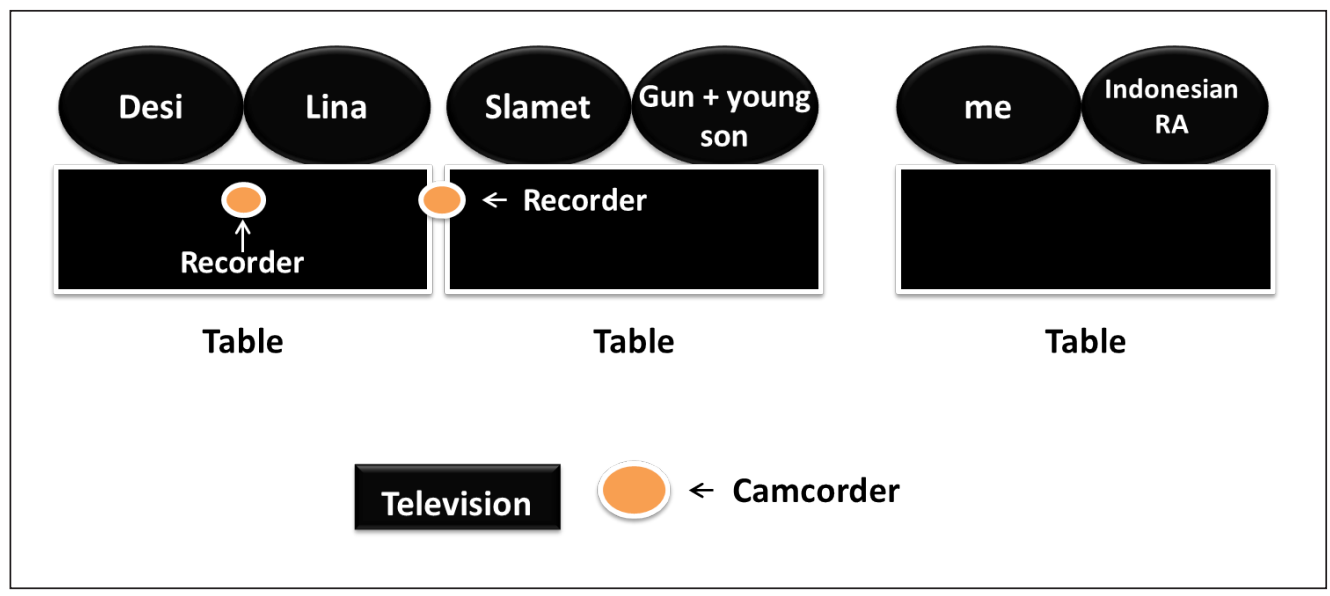

Diagram 3.1: Placement of participants relative to recording devices

became central to this process and to the identification of participants as being of a particular ethnolinguistic background. The first extract of talk that I analyze occurs after an elderly woman has narrated a letter that is being read by the main character, Dewi, and after a series of images that show a house situated within expansive grounds. (As the analysis proceeds I will introduce the transcription conventions). The import of this extract is how participants establish common ground and then move from demonstrating co-presence to engaged listening through non-minimal responses.

About a minute after seeing the images of the house and yard, we see that the topic of residence is ratified by three participants through repetitions (indicated by an underline) of vila ('villa') and its rephrasing as rumah ('house') on lines 1-3. In engaging in repetition (or the reciprocal exchange of linguistic forms), each participant is also showing the other that they recognize the referent (villa) and thus also begin to start sharing common ground. We also see that on lines 3 and 6 , Desi notes that the house is like those of the type found in Kuningan (an area located in West Java). The repetition that occurs on lines 1-3 and 6 shows how hearership and common ground is established, while Gun's non-minimal response on line 7 shows that he has not only recognized the referent (Kuningan) and is listening to Desi with his first 'heem' but that the ya gitu repeats this information in a way that suggests 'engaged listening'.

While the establishment of common ground and a non-minimal response suggest a reproduction of convivial relations, we need to see how the interaction proceeds. (For this pair I use 'reproduction' rather than 'build' because these two participants know each other through engagement in Indonesian community activities over the previous two years, though as we will see they are uncertain about whether they are members of the same ethnic community). Following the talk in extract 4.1, participants do not say much until the first advertisement break that occurs nearly ten minutes later. Some of the signs that these participants have access to before their next extended conversation include: a taxi, which drives into the driveway of Dewi's newly acquired house; and the exchanges 


\section{Gun (S)}

1 vila ya (1.0) vilanya si nike (1.0) Slamet

2 vila (0.8)

\section{Desi (S)}

3 kaya rumah di kuningan [ laughs

All

$4 \quad$ [ (laugh) $=$

Desi (S)

5

$6=\underline{\text { kuningan }} \operatorname{sih}$ (??? ???) =

Gun (S)

7 = heem . ya:: gitu.
It's a villa yeah? Its Nike's villa.

[Yes] a Villa.

Like houses in Kuningan.

(Laugh).

[In?] Kuningan (??? ???)

Heem, yeah like that.

\begin{tabular}{|c|c|}
\hline Transcription key: & \\
\hline plain font & Indicates forms stereotypically associated with Indonesian. \\
\hline BOLD ITALIC SMALL CAPS & Indicates forms stereotypically associated with Japanese. \\
\hline between words & Indicates a perceivable silence. \\
\hline Brackets with a number $(.4)$ & Indicates length of silence in tenths of a second. \\
\hline$=$ & Indicates no perceivable pause between speaker turns. \\
\hline[ & Indicates start of overlapping talk. \\
\hline ' after a word & Indicates final falling intonation. \\
\hline ? after a word & Indicates final rising intonation. \\
\hline + surrounding an utterance/word & Indicates raising of volume. \\
\hline A hash \# surrounding an utterance/word & Indicates lowering of volume. \\
\hline$>$ at the start and end of an utterance & Indicates utterance spoken faster than previous one. \\
\hline$<$ at the start and end of an utterance & Indicates utterance spoken slower than previous one. \\
\hline : within a word & Indicates sound stretch. \\
\hline CAPS & Indicates stress. \\
\hline Brackets with three ?, i.e. (???) & Indicates word that could not be transcribed. \\
\hline In extract words inside ( ) & Indicates a multimodal description. \\
\hline In English gloss words inside [ ] & $\begin{array}{l}\text { Indicates implied talk or words used to make the gloss } \\
\text { readable. }\end{array}$ \\
\hline In English gloss words inside (( )) & Indicates implied background knowledge. \\
\hline$\underline{\text { underline }}$ & $\begin{array}{l}\text { Indicates the repetition of words or utterances between } \\
\text { adjacency pairs. }\end{array}$ \\
\hline broken underline & $\begin{array}{l}\text { Indicates that the word or utterance was repeated in prior } \\
\text { talk, although it may not always be in the immediately } \\
\text { preceding turn. }\end{array}$ \\
\hline
\end{tabular}

Extract 4.1 From hearership to engaged listening and transcription key

(C) Goebel and CMDR. 2015 
Desi (S)

1 apa sih . judulnya . +judulnya apa sih . judulnya

2 apa sih $+=$

So what is the title? So what is the

title? So what is the title?

Lina

3 = apa tadi judulnya $=$

What was the title earlier?

Research Assistant

$5=$ ci . cipoa $=$

Ci, ipoa.

Desi (S)

$6=+$ +judulnya $+=$

The title.

Me

7 = cipoa $=$

Cipoa.

Research Assistant

$8=\underline{\text { cipoa }}=$

Cipoa.

Desi (S)

10 = cipoa itu apa ya (0.7)

What is [the meaning of] Cipoa?

Gun (S)

11

12

itu (while turning gaze toward Desi and smiling) bukan bahasa sunda bukan =

13

Desi (S)

$14=$ (while moving body forward and turning

15 gaze towards Gun) ya apa sih (0.6) cipoa itu

$16 \quad(0.5)$

Slamet

17 nggak tahu $=$

[I] don't know.

Desi (S)

18 = pak gun $=$

Gun (S)

19

20 = nggak tahu $($ artinya?) $\underline{\text { cipoa }} \cdot \underline{\text { cipoa }}=$

That

isn't Sundanese

is it?

Yeah so what does this [potentially

Sundanese] term Cipoa mean?

Desi (S)

$21=($ laughs $)(2.3)$

$\mathrm{Mr}^{3}$ Gun?

[I] don't know (the meaning?) of cipoa, cipoa.

Laughs.

\section{Extract 4.2 From engaged listening to discourses of sameness}

that follow between the taxi driver and the passenger (Susi), Susi and Dewi, and Dewi and the taxi driver. These signs may or may not disambiguate earlier signs about setting. For example, at the bottom of the driver's door of the taxi there is the text 'Bandung Taxi company' and the taxi also has a number plate which is prefixed with the letter ' $\mathrm{D}$ '. For those who see these signs, they may recognize them as pointing to a setting in West Java, in particular, the capital city of Bandung. There are also marked contrasts in linguistic signs exchanged in interactions between different participant pairs. For example, in the speech event involving Dewi and 
Susi, they exchange linguistic forms stereotypically associated with Indonesian. In contrast, in the interaction between Dewi and the taxi driver, which immediately follows, participants exchange many forms stereotypically associated with Sundanese, together with embodied ways of speaking not used in the earlier interaction. Shortly thereafter, there are some brief exchanges between Susi and Ucup, Dewi and Ucup, and finally an advertisement before the participants in the viewing session start to talk again (extract 4.2). The importance of this interaction lays in the continued use of non-minimal responses and the pursuit of social sameness, in this case ethnic sameness.

In this interaction there is the continued use of repetition which helps participants align with each other on a number of topics, while also establishing further common ground (e.g. the title of the serial on lines $1-9$, and the meaning of the word cipoa on lines 10-20). We also see that Gun's use of features that seem to index 'engaged listening' when speaking with Desi earlier (extract 4.1, line 7), are reciprocated through the emergence of a type of discourse of ethnic sameness between Desi and Gun. In particular, we see that while Gun's gaze direction and question left some ambiguity as to whether the question was addressed to the group or someone who he thought knew Sundanese (lines 11-13), nevertheless we see that Desi self-selects suggesting that she was the target of the question. In doing so, she moves her body in a way that she can see around Lina and Slamet to look at Gun and ask again what is the meaning of this potentially Sundanese term (lines 14-15). In asking Desi about provenance (lines 11-13), Gun appears to be saying 'you are Sundanese and may know' while also implying 'you are of the same ethnolinguistic background as me'. In short, here participants are engaged in reciprocating acknowledgements of the other's ethnic identity. Taking a sequential view it also appears that Desi ratifies this categorization by checking whether Gun-as against Slamet and Lina who she looks around-can provide a meaning for the term (lines 14-16 and 18).

While the meaning of word cipoa initially appeared to be unknown to participants, now and in this context it starts to gain a potential shared meaning (i.e. common ground about its Sundanese provenance). However, apart from the earlier mention of place (Kuningan) we are unsure what triggers a potential ethnolinguistic meaning for Gun (line 11) and Desi (lines 15-16 and 18), but we can suggest that it may have been the agreed upon potential West Java setting (extract 4.1), and/or the Sundanese usage in the interaction between the characters. In short, they seem to share some common ground where ideas of Sundaneseness are concerned.

While the social domain of cipoa as having an ethnolinguistic meaning appears to be only as wide as Gun and Desi, this topic will be revisited a number of times and by other participants throughout the viewing session and the interview, thus establishing further common ground between participants. This search for meaning continues to be tied with the ethnolinguistic identification of participants. Repetition also becomes important in other ways, especially as Slamet repeats Gun's and Desi's utterance about the provenance of the term cipoa. I suggest that the repetition in extract 4.3 needs to be seen as highlighting a move between a focus on the literal meaning of the word cipoa to one where the pursuit of conviviality is fronted through agreements on its meaning. This talk follows directly on from that represented in extract 4.2. 
In the above talk we can see that repetition continues to function as a way of establishing reference, topic, and common ground (lines 30 to 34). Just as importantly, we also see that although the topic of provenance has been established by Gun and Desi (lines 30-32), Slamet also repeats this information (lines 33-34). This informational redundancy suggests that repetition is doing something else. As with my earlier interpretations of a non-minimal response (extract 4.1 ) and discourses of sameness (extract 4.2), this repetition appears to be part of ongoing relationship building efforts, this time on the part of Slamet, who can be seen to be aligning with both Gun and Desi. On lines 35-36 we also see that Desi repeats, via her agreement (saya kira), the earlier series of repetitions involving herself, Gun, and Slamet (lines 30-34). This suggests she is reciprocating Slamet's interpersonal relationship work.

It is also interesting to note that in addition to repetition between utterances, we also now start to see repetition that does not always immediately follow a preceding turn: that is, it is temporally distant. These instances are indicated by a broken underline. For example, although Desi uses some Japanese (e.g. the use of 'eh' on line 27 that is in bold italic small caps), her whole utterance repeats what Gun said in extract 4.2 on lines 11-13. This repetition also appears to be part of ongoing efforts on the part of Desi and Gun to align with each other's stances toward the meaning of the word cipoa. In so doing, their alignment solidifies some common ground between them, while adding to their earlier pursuits of social sameness; this time sameness in their evaluations of provenance. Just as importantly, this repetition also again foregrounds Desi's claims as someone who is entitled or able to evaluate what is Sundanese and what is not. In doing this, she further strengthens the ethnolinguistic identity claims that she made in extract 4.2. In this case, something like: 'I can evaluate this term's provenance because I am Sundanese'. In so doing, she continues to engage in the pursuit of social sameness by implying that she is also of the same ethnicity as Gun.

After the talk represented in extract 4.3 there is no more extended conversation about the word cipoa until the end of the serial. Before looking at this talk, I want to take a look at one of the few large chunks of talk that occur amongst this group before the serial ends (extract 4.4). This piece of talk is interesting because in addition to the building of common ground and the use of non-minimal responses, teasing is also used for building and reproducing convivial relations amongst several of the participants. This talk is preceded by talk about the actors' spouses.

In this interaction we can see participants showing that they share some common ground and are thus the same at some level. In particular, we see that after Desi mentions the actress's name on line 3 (Dian Nitami), both Gun and Slamet demonstrate that they share some knowledge about this actress and her spouse (lines 4 and 11). As in previous talk there are also instances of nonminimal responses. The first instance of a non-minimal response is that found on line 6 where Desi answers Gun's question (line 4) with three 'yes' responses. The first seems to be a response signaling hearership, while the second iya huuh, although appearing redundant, may in fact be signaling 'engaged listening'. Similarly, while both Desi and Slamet answer Gun's question about whether the actress playing Ayu is already divorced on lines 8-11, we also see that on line 14 Desi rephrases her answer. This answer 
Me

22 tukang bohong apa =

Research Assistant

23 = tukang bohong $=$

Me

24

25

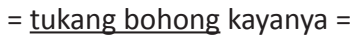

Desi (S)

26

27

$=+$ bahasa sunda $?+(0.8) \mathbf{E}: H ?=$

$\mathrm{Me}$

28

29

= kurang tahu saya (1.0)

Gun (S)

30 mungkin bandung mungkin ya .

31 daerah daerah sunda gitu'.

Desi (S)

32 [ kayanya nama daerah ya

Slamet

33 [ setingnya bandung itu . setingnya

34 (2.0) bisa nama daerah juga ya =

Desi (S)

35 = saya kira $=$

36
Slamet

$37=\underline{\text { cipoa }}=$

Desi (S)

$38=$ heeh (0.7)

Slamet

39 (??? ???) =

Research Assistant

$40=$ nama daerah itu pak.

Me

41 oh nama daerah ya .

Desi (S)

42 nggak tau tuh
Is it con artist?

Con artist.

Maybe it's like con artist.

Is it Sundanese?

REALLY

I’m not sure.

Maybe it's Bandung, maybe. A Sundanese area, yeah.

Yeah, it's like a place name.

The setting is Bandung, the setting. It can be a place name yeah.

I

think so.

Cipoa.

Yeah.

It's a place name Mr. [Zane].

Oh a place name, yeah.

I don't know.

\section{Extract 4.3 Repetition and the linking of language with place}

repeats what has already been said (awet awet which literally means 'to last long', but here meaning something like 'still together'). In so doing, her talk is again more than required and invites us to interpret this type of repetition as helping build convivial relations, this time with Slamet, who has aligned with Desi on the question of whether the actor is divorced or not. 


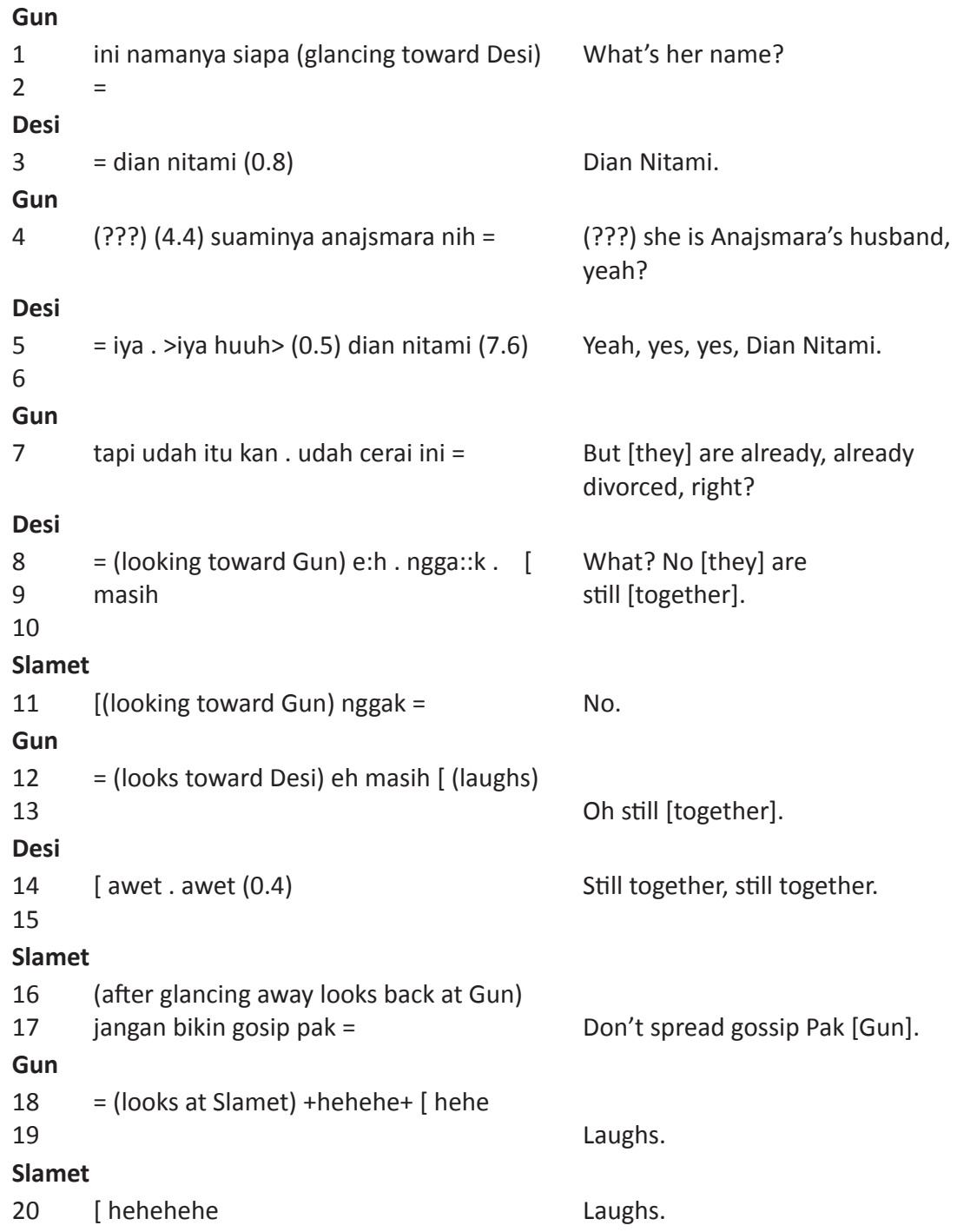

No.

Oh still [together].

Still together, still together.

Don't spread gossip Pak [Gun].

Laughs.

Laughs.

\section{Extract 4.4 Teasing and conviviality}

We also see that although Desi aligns with Slamet, Slamet is also quick to try and build convivial relations with Gun by teasingly accusing him of spreading gossip (lines 16-17). The tease touches on multiple ideologies about gossip and piousness. For example, Gun arrived a little earlier than the other participants and was finishing his afternoon prayer as other participants arrived. Performing his prayers indexed not only his Islamic identity but his piety insofar as praying is being pious. Engaging in gossip, which is categorized as sinful, is thus part of the joke. The other part is that while gossip can often be meant to reach the person being gossiped about (Besnier 2009), in this setting the people being gossiped 
about would be very unlikely to hear this gossip. Gun appears to orient to this joke through his loud laughter (indicated by a '+' surrounding the hehe) and his gaze (lines 18-19). Again, given that this sequence is not informational, it seems to invite an interpretation of another local strategy for producing convivial relations.

After this sequence participants do not say much until the end of the serial when Dewi's grandmother makes her fourth and final appearance to warn Dewi about con artists. At this stage one of the viewers, Slamet, reiterates that the grandmother is a ghost before then hearing the use of word cipoa. Upon hearing this term, he then initiates the talk represented in extract 4.5 . There are a number of important aspects to this extract, including repetition that enables convivial relations to be established between Lina and Desi and renewed discussion over the provenance of the term cipoa, which enable the pursuit of conviviality between Desi and Slamet in the interview that follows.

In the above talk we can see that the provenance of the term cipoa again becomes a topic as Slamet suggests cipoa is Sundanese (lines 2-3). Desi does not align fully with Slamet's interpretation through her self-identifying as a Sundanese who has never heard the term (lines 7-8). While her comment repeats her uncertainty about provenance, which she shared with Gun (extracts 4.2-4.3), we can see that this talk also represents a point in which explicit social identification occurs through Desi's claims to native speakership. This social identification occurs as part of another sequence in which participants assign an ethnic meaning to the word cipoa. We also see that Slamet, although not making native speaker claims, defers to kamus besar 'Authorative Dictionary' (lines 9-12 and 15-16) where he notes we may find this term. (Kamus Besar has its authority by being both written and endorsed by the government through the government funded language center in Jakarta.) In other words, Slamet is unconvinced that its provenance is not Sundanese despite Desi's claims of not knowing the term. His position on this does not change as the viewing session is brought to a close and he notes that it is old archaic Sundanese on lines 31-32. In the early part of the interview that follows immediately after this viewing session, however, Desi takes up the theme of archaism in a way that suggests alignment with Slamet on a number of levels: in short, they too begin to build some common ground.

Lina also offers a meaning for cipoa, which does not relate to provenance, but rather to morality, especially a tendency to tell white lies or not be entirely honest (lines 13-14). This interpretation is oriented to by Desi through her repetition of bohong 'to tell white lies or not be entirely honest' (line 17) and her upgrade of this term to menipu 'to deceive' (line 20), which Lina ratifies through her expansion of the meaning to 'someone who doesn't know or talks rubbish' (lines 23-24). In short, the social domain of the meaning of cipoa as relating to a moral trait also widens from me (extract 4.3) to include Desi and Lina. This sequence also appears to be similar to earlier instances of repetition insofar as they function not only as signs of topic alignment and the establishment of common ground, but also as more than is necessary in informational terms. In other words, the extra repetition from line 15 onwards seems to be doing more than just repeating the meaning of the term as something to do with dishonesty. Instead, this repetition seems to be contributing to the building 


\section{Slamet}

1 neneknya hantu (1.8) +oh+ (1.8) oh (looks

2 at Desi) cipoa itu bahasa ini deh. sunda

3 kayaknya (0.8)

Desi

4 nggak tahu =

Slamet

$5=$ cipoa . orang suka cipoa $=$

Desi

6 = tiga puluh tiga tahun jadi orang sunda baru

7 denger (laughs) $=$

8

\section{Slamet}

$9=$ cari di ini (looks at Desi). (turns back to

10 look at Slamet) apa kamus bahasa Indonesia

11 sama anu. kamus.

12

Lina

13 orang suka cipoa:: katanya . [ suka bohong

14 apa (1.0)

\section{Slamet > Gun}

15 [ bahasa indonesia. kamus besar bahasa

16 indonesia $=$

17

Desi

18 = bohong $=$

Lina

19 = untuk menutupi kekurangannya =

20

Desi

$21=\underline{\text { menipu }} \cdot$ eh $=$

Slamet

22 = cipoaé apa ya (1.75)

23

Lina

24 suka:: berdusta mungkin .

25 ndak tahu itu (1.2) ah omong kosong (0.9)

\section{Slamet}

\section{6 [ bahasa}

Me

27 [ mudah mudahan tidak begitu

28 membosankan =

Desi

29 =nggak . bagus (while laughing) [ lucu

30

Slamet

31 [ bahasa sunda . bahasa sunda kuno (2.7)

32 bahasa sunda kuno
Her grandmother is a ghost. Oh. Oh it looks like cipoa is Sundanese.

[I] don't know

A person who likes to cipoa.

[I've] been a Sundanese for thirty-three years and [I've] just heard [this word]

Look in this,

what is it

the Indonesian dictionary and the um,

dictionary.

She said "Those who like to cipoa have a tendency to tell white lies all the time, or something like that."

Indonesian, the Large Authorative

Indonesian dictionary.

$\underline{\text { To tell white lies. }}$

To hide

their inadequacies.

To deceive, eh?

What does Cipoa mean?

Maybe [someone] who regularly deceives, [someone who] doesn't know, [or] talks rubbish.

Its language

Hopefully this hasn't been too boring.

No, it was good, it was funny.

It was Sundanese, old Sundanese, old Sundanese.

Extract 4.5 Negotiating meanings and conviviality 
of convivial relations, this time between Desi and Lina, who to this point have not interacted much.

\section{IDENTITY, CONVIVIALITY, AND MEANING}

In the rest of my analysis I focus on talk that occurred in the interview that immediately followed the viewing session. As participants move into a different speech situation (e.g. from a viewing session to an interview) they continue to engage in the building of convivial relations using the features of talk discussed thus far. This talk is, in part, facilitated by the common ground thus far established between participants, including the various meanings of the word cipoa. What is also striking about this talk is that while thus far the meaning of cipoa has been multiple, in the talk in the interview that follows participants increasingly align with each other about the meanings of this word. The conversation below occurs after I bring up the talk about the word cipoa. It represents both the continued pursuit of ethnic sameness (Desi and Gun), the establishment of some common ground between Desi and Slamet, and the pursuit of sameness in opinions on the part of Desi and Lina.

In keeping with her earlier position on the provenance of cipoa (e.g. extract 4.3 on lines 23-24 and extract 4.5 on lines 7-8), Desi reiterates that the term is probably not Sundanese (lines 2-3); a position Gun appears to ratify (line 4). In doing so, she appears to be also identifying Gun as someone with native speaker expertise like herself. When viewed together with earlier instances of repetition, this pursuit of social sameness seems to also add to the building of convivial relations between these two participants. Slamet, however, does not fully align with this suggestion. Instead, on lines 5-9 he reiterates his earlier position (see extract 4.5) about its probable existence in a dictionary and that it is probably an uncommon or archaic form. In doing so, he adds 'uncommon' to the term's ever expanding meanings. The social domain of this meaning also seems to widen to include Desi and Lina, who appear to ratify this meaning on line 10 and lines 11-12 respectively. This ratification represents an occasion where Desi and Slamet, who have earlier disagreed on provenance, now achieve some common ground.

After again re-iterating one of the term's meanings as relating to a negative personal trait (lines 13-14), in the talk that follows immediately afterwards, Desi repeats her alignment with Slamet and Lina around the 'archaicness' or 'uncommonness' of the term cipoa (extract 5.2). This repetition seems to be going beyond conversational alignment between Desi, Slamet, and Lina by repeating the information 'we have aligned/agreed on this topic' to do conviviality. In other words, in extract 5.2 participants are engaging in pursuing sameness in epistemic stance.

Here we see Desi again pursuing social sameness by literally asking Gun 'are you the same as me' through her utterance on lines 29-30 eh orang sunda bukan ('You're Sundanese aren't you'). On lines 32-33 Slamet teases Gun, this time about Gun's ambiguous native speaker credentials given his near decade-long stay in Japan. This is yet one further example of how teasing is used to build convivial relations among a group of relative strangers. We also see that Desi is repeating Slamet's earlier suggestion that the word cipoa is old or archaic on lines 21-25 and 27-28. In so doing, she repeats her earlier alignment with Slamet about the archaicness of the form, while 


\begin{tabular}{|c|c|c|}
\hline \multicolumn{3}{|c|}{ Desi } \\
\hline 1 & = sebenarnya bukan yang jelas . (starts & Actually, it is not clear. \\
\hline 2 & looking at Gun) kayaknya bukan bahasa & It appears that it isn't Sundanese, \\
\hline 3 & sunda itu . [ kayanya istilah & it appears like a term ... \\
\hline \multicolumn{3}{|c|}{ Gun } \\
\hline 4 & [ kayaknya (???) & That's what it appears like (???). \\
\hline \multicolumn{3}{|c|}{ Slamet } \\
\hline 5 & [ kayaknya. kayaknya & It's like, it's like if we opened the \\
\hline 6 & kalau kita buka kamus besar kayaknya ada & authorative dictionary, it's like the term \\
\hline 7 & itu . cipoa itu (0.5) tapi bahasa yang jarang & cipoa would be there. But it's like language \\
\hline 8 & dipakai kayaknya . tidak [ umum \#jadi\# & that is rarely used, so it's not common. \\
\hline 9 & & \\
\hline \multicolumn{3}{|c|}{ Desi } \\
\hline 10 & [ bahasa karuhun $=$ & Ancestor's language. \\
\hline \multicolumn{3}{|c|}{ Lina } \\
\hline 11 & $=\underline{\text { bahasa tidak }}[$ & Language [which] isn't \\
\hline 12 & $\underline{\text { umum }}$ & common. \\
\hline \multicolumn{3}{|c|}{ Slamet } \\
\hline 13 & [ jangan suka cipoa (1.1) \#untuk menutupi & Don't cipoa to \\
\hline 14 & kekurangannva\# (1.8) & cover up inadequacies. \\
\hline
\end{tabular}

\section{Extract 5.1 Naming languages, native speakership, and pursuing social sameness}

repeating Lina's earlier contribution about the form's uncommonness.

In addition to highlighting a return to the activity of working out the provenance of the term cipoa, we also see how this activity helps in the social identification of participants. For example, Desi tries to gain alignment from Gun (lines 27-28), before checking his native speaker credentials (29-30). In doing so, we get to again see the importance Desi places on native speakership when talking about language. In this instance, it appears that her explanation of the term cipoa rests both on the identity that has emerged over interactional time (that is, her identity as a native speaker of Sundanese), and her wish to have another native speaker (in this case Gun) align with her ideas about why she does not know this term.

In the next extract we see that Slamet, who has actually lived and studied for five years in Bandung (stereotypically a heartland of Sundanese speakers), now also appears to be encouraged by Desi to explain aspects of Sundaneseness. In their interactions we get further insights into how repetition helps to establish more common ground between them as they pursue sameness in opinions about provenance, while further solidifying emerging convivial relations between these two. The talk in extract 5.3 follows almost immediately from the talk represented in extract 5.2 (I have deleted two turns by Lina and Desi). 


\section{$\mathrm{Me}$}

15 jadi ada? yang bahasa bahasa lain yang

16 tadi \#juga\# . mungkin ndak (1.0) [ ndak

17 mengerti gitu .

\section{Slamet}

18 [ heem

Desi

19 mungkin kan . kalau di bahasa sunda

20 itu pak [author]' . ah bahasa sunda itu

21 ada istilah bahasa karuhun ya . >bahasa

22 karuhun itu $>$ bahasa yang tidak digunakan

23 sehari hari:: . tapi sebenarnya orang

24 orang tua di:: . tanah jawa barat itu

25 menggunakan gitu'.

\section{Slamet}

26 [ heem

Desi

27 [ mungkin . generasinya saya . pak gun

28 \#gitu\# tidak begitu mengena::I . (looks

29 and points open hand at Gun) +eh+

30 >orang sunda> bukan .

Gun

31 heem $=$

Slamet

32 = orang [ sunda tapi tidak pernah di sunda

33 \#dia\# (said while smiling)
So is there other language from

earlier that maybe [you] didn't, didn't

understand, you know?

Yes.

Maybe, right, if it is Sundanese

Mr. [author's name], ah Sundanese has

a term bahasa karuhan yeah. Bahasa

karuhan means a language that isn't used daily, but actually the elderly in West Java use it, you know.

Yes.

Maybe my generation [and] Mr. Gun's don't really know the [language or its words]. Oops!

[You're] Sundanese aren't [you]?

Yes.

[He's] Sundanese but rarely lives in Sunda. (a joke pointing to Gun's near decade-long stay in Japan)

\section{Extract 5.2 It is uncommon Sundanese spoken by the elderly}

In extract 5.3 we see the continued use of repetition as a way of showing hearership, for establishing reference and for establishing common ground. For example, Lina and Desi align on the topic of accent on lines 44-46, and Desi and Slamet align on the topic of the philosophy of life (lines 51-52). When viewed in relation to the prior talk in extract 5.2-where 'archaic' become a ratified meaning of the word cipoa amongst these two-we can say that this talk repeats much of the earlier talk. In doing so, it adds to their earlier alignments in a way that builds upon the conviviality that has occurred throughout the whole session (viewing and interview). What appears even more striking is while Desi contested Slamet's knowledge about things Sundanese (extract 4.5 lines 7-8), here she has made a number of concessions that have helped build common ground between the two, while also building convivial relations between them.

In particular, although Desi continues to foreground her expertise and identity as a Sundanese through her positive evaluation of the authenticity of the televised representations of 


\section{Desi (S)}

36 jadi e:: . >buat generasi saya tida::k>

37 tidak mengenal bahasa \#itu\# (0.6)

38 tetapi karena yang menjadi neneknya

39 ini sangat sunda. [ sundanese banget gitu ya'.

\section{Slamet}

40 [ hmmm (while nodding head)

$\mathrm{Me}$

41 gi . gimana [ a apa . apa yang? . misalnya

Desi (S)

42 [ (orang sunda?) (1.0) +dari dialek+ .

43 dari dialek . dari mis [ al kan

Lina

44 [ logat $=$

Desi (S)

45 = logat dari bicara itu (0.5) banyak

46 bahasa sunda keluar . dari . dari (0.5)

47

\section{Slamet}

48 psik psikologinya . (looking at Desi)

Desi (S)

49 [ heeh

Slamet

50 [ ah bukan psikologi apa namanya .

51 (looks at Desi) filsafat hidupnya:: =

Desi (S)

52 = filsafat hidupnya itu:? . jadi kalau

53 membersihkan halaman rumah?

54 maka:? . (looks at Slamet and smiles)

55 >apa lagi>
So er for my generation [I] don't don't know that language. But

because the grandmother is very

Sundanese, very Sundanese, you know.

Yeah.

(False start), why, what, what is it, for example?

((Sundanese?)) From [the] dialect, from the dialect, from for example, right.

Accent.

The speaking accent, a lot of Sundanese also came with it. From, from

Psch, their psychology.

Yes

Ah not their psychology, what is it, their philosophy of life.

Their philosophy of life. So if you clean your yard, then ... what else Slamet?

\section{Extract 5.3 The grandmother is just so Sundanese}

Sundaneseness that she had just watched (lines 38-39), nevertheless she also ratifies Slamet's comments about things Sundanese. For example, after seeking approval from Desi on lines 48 and 51, Desi ratifies his contribution through the use of 'heeh' (line 49), as well as repetition and expansion (lines 53-55). Slamet goes on to explain that the reason for classifying cipoa as uncommon and archaic relates to the old-fashioned social practices engaged in by the old woman represented in the soap. In this case it is her philosophy of life, which Slamet discusses at length after being invited to do so by Desi (on line 55). Without providing a transcript of the rest of the talk, Slamet notes that this philosophy relates to something like a clean environment around the home 
and means that we have a clean spirit and healthy life.

In summary, across another speech situation (an interview), we see the continued use of a number of features that seem to be used for building convivial relations amongst this group of Indonesians, including the use of teasing, the social pursuit of sameness, and repetition (both temporally close and that which is much earlier in the group session). The use of these features is intimately tied to the establishing of common ground (personal ethnic backgrounds, provenance, archaicness, and traditional philosophies of life) as well as continued acts of social identification.

\section{CONCLUSION}

This paper added to a small but growing body of sociolinguistic work by focusing upon an old question in the Humanities and Social Sciences, namely how do people from diverse backgrounds do conviviality. I explored the relationships between the use of strings of small response tokens (non-minimal responses) and a form of linguistic reciprocity commonly referred to as 'repetition', how these features both helped to establish common ground and pursue social sameness, and how all of this figured in the building and maintenance of convivial relations between a group of Indonesians living in Japan. My empirical focus was on the conversations of these Indonesians as they engaged in viewing an Indonesian soap, and as they engaged in a group interview afterwards.

Repetition of words and small utterances was the primary way in which participants went about establishing reference and common ground. While some common ground was emergent, nevertheless the agreement on referents formed the basis for subsequent convivial talk. The establishment of common ground through repetition (i.e. the reciprocal exchange of linguistic forms) was also part of the more general processes of building convivial relations between these Indonesians. Conviviality was also built through the use of nonminimal responses, teasing, and the social pursuit of sameness; in this case sameness in terms of ethnolinguistic background and in opinions about the meaning of the word cipoa. As Goffman's (1971) work suggests, the import of this type of conversational work is not just the conviviality that is established in the immediate setting, but the potential for future conviviality in other settings.

For this group of Indonesians it is understandable that they engaged in this type of talk (instead of say staying silent throughout the two-hour session and not attending the subsequent three viewing and interviewing sessions) because their situation as sojourners required them to engage in conviviality. Indeed, most had gone from being reasonably welloff Indonesians in Indonesia with dense networks of friends and kin who could be relied upon to offer financial support and physical labor in times of need, to being relatively poor and needing to rely upon other unfamiliar Indonesians to provide financial and physical support as well as information about how best to eke out a living in Japan. Access to such networks required and was reproduced by attending regular gatherings and by engaging in convivial practices in such gatherings. Thus, by actively working on establishing common ground and pursuing social sameness, participants (re)produced the basis for subsequent convivial relations and access to the important networks that would help them while sojourning in Japan. 


\section{NOTES}

1. This is a revised version of a working paper entitled 'Indonesians doing togetherness in Japan', which was first presented as part of a panel titled 'Constructing identities in transnational spaces' at the American Association for Applied Linguistics conference in Boston in March 2012. It then appeared in 2013 as a working paper (No. 67) in the series Tilburg Papers in Culture Studies. I subsequently presented this version at a workshop at Tilburg University. I would like to thank Jan Blommaert who engaged with the paper in 2012 and Max Spotti, Piia Varis, Sanna Lehtonen, Tom van Nuenen, Paul Mutsaers, and the dozen postgraduate students who engaged with this paper during my stay at Tilburg University. As always, responsibility for the final version lies squarely with me.

2. This research was made possible by a grant from the Japan Society for the Promotion of Science (Grant No. C20520380). I would like to thank the participants in this study for their willingness to be involved and for their graciousness and good-humored responses to my questions. I would also like to thank a team of Indonesian research assistants who have worked with me on this project, including Eni, Riris, Inu, and Puji.

3. Pak is literally 'Mr.' but interactionally is typically used as a kin term and has indexical relationships with ideas about fatherhood and the offering of respect to elders.

\section{REFERENCES}

Amin, Ash. 2013. Land of Strangers.

Hoboken: Wiley.

Ang, Ien. 2003. Together-in-difference: beyond diaspora into hybridity. Asian Studies Review 27: 141-154.

Antaki, Charles and Sue Widdicombe. 1998. Identity as an achievement and as a tool.
In Charles Antaki and Sue Widdicombe (eds). Identities in Talk. London: Sage Publications. 1-14.

Berman, Laine. 1998. Speaking through the Silence: Narratives, Social Conventions, and Power in Java. New York: Oxford University Press.

Besnier, Niko. 2009. Gossip and the Everyday Production of Politics. Honolulu: University of Hawai'i Press.

Bjork-Willen, Polly. 2007. Participation in multilingual preschool play: Shadowing and crossing as interactional resources. Journal of Pragmatics 39 (12): 2133-2158.

Blommaert, Jan. 2013. Ethnography, Superdiversity and Linguistic Landscapes: Chronicles of Complexity. Bristol: Multilingual Matters.

Brettell, Caroline. 2003. Anthropology and Migration: Essays on Transnationalism, Ethnicity, and Identity. Walnut Creek, CA.: Altamira Press.

Bucholtz, Mary and Kira Hall. 2004. Theorizing identity in language and sexuality research. Language in Society 33 (4): 469-515.

Bunnell, Tim, Sallie Yea, Linda Peake, Tracey Skelton, and Monica Smith. 2012. Geographies of friendships. Progress in Human Geography 36 (4): 490-507.

Coupland, Justine (ed). 2000. Small Talk. London: Longman.

Coupland, Justine. 2003. Small Talk: Social Functions. Research on Language E Social Interaction 36 (1): 1-6.

Enfield, Nicholas. 2006. Social consequences of common ground. In Nicholas Enfield and Stephen Levinson (eds). Roots of Human Sociality: Culture, Cognition and Interaction. Oxford: Berg. 399-430.

Goebel, Zane. 2010. Language, Migration and Identity: Neighborhood Talk in Indonesia. Cambridge: Cambridge University Press.

Goffman, Erving. 1971. Relations in Public: Microstudies of the Public Order. New York: Basic Books.

Gumperz, John. 1982. Discourse Strategies. Cambridge: Cambridge University Press.

Hanks, William. 2006. Joint commitment and common ground in a ritual event. In Nicholas Enfield and Stephen Levinson (eds). Roots of Human Sociality: Culture, 
Cognition and Interaction. Oxford: Berg. 299-328.

Hobart, Mark. 2001. Drunk on the screen: Balinese conversations about television and advertising. In Brian Moeran (ed). Asian Media Productions. London: Routledge. 197-219.

Karner, Christian and David Parker. 2010. Conviviality and conflict: Pluralism, resilience and hope in inner-City Birmingham. Journal of Ethnic and Migration Studies 37 (3): 355-372.

Landau, Loren B. and Iriann Freemantle. 2009. Tactical cosmopolitanism and idioms of belonging: Insertion and self-exclusion in Johannesburg. Journal of Ethnic and Migration Studies 36 (3): 375-390.

Lempert, Michael. 2014. Imitation. Annual Review of Anthropology 43 (1): 379-395.

Malinowski, Bronislaw. 1996 [1922]. The essentials of the Kula. In R. Jon McGee and Richard L. Warms (eds). Anthropological Theory: An Introductory History. Mountain View, Calif.: Mayfield Pub. Co. 157-172.

Mauss, Marcel. 1966 [1925]. The Gift: Forms and Functions of Exchange in Archaic Societies. Translated by Ian Cunnison. London: Cohen and West LTD.

McCarthy, Michael. 2003. Talking back: 'Small' interactional response tokens in everyday conversation. Research on Language E् Social Interaction 36 (1): 33-63.

Nilan, Pam. 2001. Gendered dreams: Women watching sinetron (soap operas) on Indonesian TV. Indonesia and the Malay Worlds 29 (84): 85-98.

Rachmah, Ida. 2006. Watching Indonesian sinetron: Imagining communities around the television. Unpublished PhD dissertation. Perth: Curtain University.

Rampton, Ben. 1995. Crossing: Language and Ethnicity among Adolescents. London: Longman.
Ryoo, Hye-Kyung. 2005. Achieving friendly interactions: A study of service encounters between Korean shopkeepers and African-American customers. Discourse and Society 16 (1): 79-105.

Strachle, Carolyn. 1993. "Samuel?" "Yes, Dear?": Teasing and conversational rapport. In Deborah Tannen (ed). Framing in Discourse. New York: Oxford University Press. 210-230.

Tannen, Deborah. 1984. Conversational Style: Analyzing Talk among Friends. Norwood, New Jersey: Ablex.

Tannen, Deborah. 1989. Talking Voices: Repetition, Dialogue, and Imagery in Conversational Discourse. Cambridge: Cambridge University Press.

Thrift, Nigel. 2005. But malice aforethought: Cities and the natural history of hatred. Transactions of the Institute of British Geographers 30 (2): 133-150.

Vertovec, Steven. 2007. Super-diversity and its implications. Ethnic and Racial Studies 30 (6): 1024-1053.

Werbner, Pnina. 1997. Introduction: The dialectics of cultural hybridity. In Pnina Werbner and Tariq Modood (eds). Debating Cultural Hybridity. Multi-cultural Identities and the Politics of Anti-racism.

London \& New Jersey: Zed Books. 1-28.

Williams, Quentin and Christopher Stroud. 2013. Multilingualism in transformative spaces: Contact and conviviality. Language Policy 12 (4): 289-311.

Wise, Amanda. 2009. Everyday multiculturalism: Transversal crossings and working class cosmopolitans. In Amanda Wise and Selvaraj Velayutham (eds). Everyday Multiculturalism. New York: Palgrave MacMillan. 21-45. Wortham, Stanton. 2006. Learning Identity: The Joint Emergence of Social Identification and Academic Learning. Cambridge: Cambridge University Press. 